\title{
NEWBORN SCREENING IN SLOVENIA PRESEJANJE NOVOROJENCEV V SLOVENIJI
}

\author{
Andraž ŠMON1 ${ }^{1}$, Urh GROŠELJ1, Mojca ŽERJAV TANŠEK ${ }^{1}$, Ajda BIČEK², \\ Adrijana OBLAK ${ }^{2}$, Mirjana ZUPANČIČ ${ }^{3}$, Ciril KRŽIŠNIK ${ }^{4}$, Barbka REPIČ LAMPRET ${ }^{3}$, \\ Simona MURKO ${ }^{3}$, Sergej HOJKER ${ }^{2}$, Tadej BATTELINO ${ }^{1,4, *}$
}

'University Medical Centre Ljubljana, University Children's Hospital, Department of Endocrinology, Diabetes and Metabolic Diseases, Bohoriceva 20, 1000 Ljubljana, Slovenia

2University Medical Centre Ljubljana, Department of Nuclear Medicine, Zaloska cesta 7, 1000 Ljubljana, Slovenia 3University Medical Centre Ljubljana, University Children's Hospital, Unit for Special Laboratory Diagnostics, Vrazov trg 1, 1000 Ljubljana, Slovenia

${ }^{4}$ University of Ljubljana, Faculty of Medicine, Vrazov trg 2, 1000 Ljubljana, Slovenia

ABSTRACT

Keywords: congenital hypothyroidism, phenylketonuria, mass screening, incidence, Slovenia
Introduction. Newborn screening in whole Slovenia started in 1979 with screening for phenylketonuria (PKU). Congenital hypothyroidism $(\mathrm{CH})$ was added into the programme in 1981 . The aim of this study was to analyse the data of neonatal screening in Slovenia from 1993 to 2012 for PKU, and from 1991 to 2012 for CH.

Methods. Blood samples were collected from the heels of newborns between the third and the fifth day after birth. Fluorometric method was used for screening for PKU, CH screening was done by dissociationenhanced lanthanide fluorescent immunoassay (DELFIA).

Results. From 1993 to 2012, from 385,831 newborns 57 were identified with PKU. 184 newborns out of 427,396 screened from 1991 to 2012, were confirmed for $\mathrm{CH}$. Incidences of PKU and CH in the periods stated are $1: 6769$ and 1:2323, respectively.

Conclusions. Successful implementation of newborn screening for PKU and $\mathrm{CH}$ has helped in preventing serious disabilities of the affected children. Adding screening for new metabolic diseases in the future would be beneficial.

Uvod. Presejanje novorojencev v Sloveniji se je začelo leta 1979 s presejanjem za fenilketonurijo (PKU). Leta 1981 je bil v program presejanja dodan še kongenitalni hipotireoidizem (CH). Cilj te raziskave je analiza podatkov presejanja novorojencev v Sloveniji v obdobju med letoma 1993 in 2012 za PKU ter med letoma 1991 in 2012 za CH.

Metode. Vzorci krvi so bili odvzeti petim novorojencem med tretjim in petim dnem življenja. Pri presejanju za PKU se uporablja fluorometrična metoda, presejanje za CH pa poteka z metodo DELFIA.

Rezultati. Od leta 1993 do leta 2012 je bil presejalni test za PKU izveden pri 358.831 novorojencih. Pri 57 otrocih je bil PKU potrjen. Pri 427.396 novorojencih med letoma 1991 in 2012 je bil izveden presejalni test za $\mathrm{CH}$. Pri 184 otrocih je bil $\mathrm{CH}$ potrjen. $\mathrm{V}$ navedenih obdobjih je bila incidenca PKU 1:6769 in incidenca CH 1:2323.

Zaključki. Uspešna implementacija presejanja novorojencev za PKU in $\mathrm{CH}$ je imela pomembno vlogo pri preprečevanju resnih zapletov pri obolelih otrocih. Smiselno bi bilo v program presejanja vključiti nove metabolne bolezni. 


\section{INTRODUCTION}

Newborn screening for metabolic diseases is an important public health programme, as an early identification of affected children can help in preventing disabilities and even death $(1,2)$. It is available in many developed countries and in all neighbouring countries of Slovenia (36). Newborn screening in Slovenia started in 1979 with screening for phenylketonuria (PKU) (7). Screening for congenital hypothyroidism $(\mathrm{CH})$ started 2 years later in 1981 (8). PKU is an inborn error in amino acid metabolism, caused by mutations of phenylalanine hydroxylase gene. Phenylalanine hydroxylase converts phenylalanine to tyrosine, decreased activity of the enzyme leads to increased phenylalanine in the blood and the brain, which can have detrimental effects, such as intellectual impairment and other symptoms, like autism, seizures and motor deficits (9). $\mathrm{CH}$, one of the most common preventable causes of mental retardation, is a thyroid hormone deficiency present at birth (10). Screening for $\mathrm{PKU}$ and $\mathrm{CH}$ in Slovenia helped to improve the outcome of most of the affected children. Screening for both diseases has been shown to be cost saving $(11,12)$.

\section{METHODS}

\subsection{Organisation}

Analyses were done at the University Medical Centre Ljubljana, Department of Nuclear Medicine. Only serum phenylalanine (Phe) was analysed at the University Medical Centre Ljubljana, University Children's Hospital, Unit for Special Laboratory Diagnostics. All children with elevated Phe and TSH values were followed-up at the University Medical Centre Ljubljana, University Children's Hospital, Department of Endocrinology, Diabetes and Metabolic Diseases.

\subsection{Specimen Collection}

Blood samples from newborns were collected between the third and the fifth day after birth from the heels of newborns. Samples were collected onto the filter paper Whatman 903 and dried. The dried blood samples were sent by mail (from nurseries not located in Ljubljana) or by a courier service (from the nursery in Ljubljana) to the Department of Nuclear Medicine.

\subsection{Laboratory Methods}

PKU was detected by quantitative determination of Phe in dried blood spot. From January 1979 to June 1992, screening for PKU was performed by the Guthrie method with the Phe cut off value of $0.12 \mathrm{mmol} / \mathrm{L}$ (7). Since July 1992, a fluorometric method was used (Neonatal Phenylalanine kit, PerkinElmer). For the fluorometric method, Phe values $<0.12 \mathrm{mmol} / \mathrm{L}$ were treated as normal after the responsible analyst approved them. Values of Phe between $0.12 \mathrm{mmol} / \mathrm{L}$ and $0.20 \mathrm{mmol} / \mathrm{L}$, including 0.12 $\mathrm{mmol} / \mathrm{L}$ and $0.20 \mathrm{mmol} / \mathrm{L}$, were considered as increased threshold values. In this case, the analysis was repeated from a new dried blood spot which was acquired from the nursery. Increased values of Phe $\geq 0.20 \mathrm{mmol} / \mathrm{L}$ required confirmational analysis of Phe, which was quantified from a new serum blood sample. Serum blood sample was taken after contacting the nursery where the original sample was taken. It was quantified by the use of the ninhydrin and L-leucyl-L-alanine fluorometric test. PKU was confirmed by elevated serum Phe.

$\mathrm{CH}$ was detected by measuring the value of thyroidstimulating hormone (TSH). From August 1981 to April 1989 , radioimmunoassay (RIA) was used for this purpose (8). From then on, analysis was done by dissociationenhanced lanthanide fluorescent immunoassay (DELFIA® Neonatal hTSH kit, PerkinElmer). Values for TSH were given as $\mathrm{mU} / \mathrm{L}$. The cut off value for RIA was $20 \mathrm{mU} / \mathrm{L}$. The measured values with the current method were evaluated as follows. Values up to $8 \mathrm{mU} / \mathrm{L}$ were considered normal after the approval by the responsible analyst. In the case of TSH, values between 8 and $20 \mathrm{mU} / \mathrm{L}$, including 8 and $20 \mathrm{mU} / \mathrm{L}$, were considered as increased threshold values, analysis was repeated from a new dried blood spot acquired from the nursery. When TSH values were $\geq 20 \mathrm{mU} / \mathrm{L}$, they were considered as increased values and confirmational analysis of TSH was done from a new serum blood sample taken after contacting the nursery where the original sample was taken. Analyses were done by ADVIA Centaur TSH-Ultra assay (Siemens). $\mathrm{CH}$ was confirmed by elevated serum TSH.

\subsection{Quality Control}

The dried blood spot controls were included in every analytical batch to monitor accuracy and precision within the system. The laboratory participated in UK NEQUAS scheme (http://www.ukneqas.org.uk/) for external international quality control for PKU and $\mathrm{CH}$, and in RFB DGKL scheme (http://www.dgkl-rfb.de/) for external international quality control for $\mathrm{CH}$.

\section{RESULTS}

\subsection{Metabolic Phenotypes of PKU Patients}

PKU was classified into different metabolic phenotypes, based on the measured Phe value in blood. Normal Phe value was between $0.05 \mathrm{mmol} / \mathrm{L}$ and $0.12 \mathrm{mmol} / \mathrm{L}$. In mild hyperphenylalaninaemia, which does not require any dietary treatment to prevent neurological damage, Phe values were between $0.12 \mathrm{mmol} / \mathrm{L}$ and $0.60 \mathrm{mmol} / \mathrm{L}(9$, 13). In mild PKU, Phe values were between $0.60 \mathrm{mmol} / \mathrm{L}$ and $0.90 \mathrm{mmol} / \mathrm{L}$, in moderate $\mathrm{PKU}$, Phe values were between $0.90 \mathrm{mmol} / \mathrm{L}$ and $1.20 \mathrm{mmol} / \mathrm{L}$ (some authors 
do not use the term moderate PKU and consider mild PKU between $0.60 \mathrm{mmol} / \mathrm{L}$ and $1.20 \mathrm{mmol} / \mathrm{L})$. Patients with classic phenylketonuria had Phe values higher 1.20 $\mathrm{mmol} / \mathrm{L}(9,13)$.

\subsection{Incidence of PKU and $\mathrm{CH}$}

Results for PKU screening from 1993 to 2012, and for $\mathrm{CH}$ screening from 1991 to 2012, are given in Table 1 and Table 2. The numbers of positive results for both PKU and $\mathrm{CH}$ are given for the period between 2000 and 2012, older data was not available. Results of PKU screening from the implementation of screening until April 1993, and of CH screening until July 1991, were already published (7, 8). From 1993 to 2012, 57 cases were diagnosed positive for PKU, which is up to 6 positive cases of PKU per year. Between 1991 and 2012, there were from 3 to 16 positive cases of $\mathrm{CH}$ annually, which amounts to a total of 184 patients with $\mathrm{CH}$. That gives average incidences of 1:6769 for PKU and 1:2323 for $\mathrm{CH}$. Incidence of PKU in Europe is between 1:3000 and 1:30000, of $\mathrm{CH}$ between 1:1300 and $1: 13000$ (14).

Table 1. Neonatal screening for PKU in Slovenia from 1993 to 2012 (the number of live births annually was taken from the webpage of Statistical Office of the Republic of Slovenia, www.stat.si). N/A = data not available. $I=$ Incidence can not be calculated as there were no confirmed cases in that year.

Table 2. Neonatal screening for $\mathrm{CH}$ in Slovenia from 1991 to 2012 (the number of live births annually was taken from the webpage of Statistical Office of the Republic of Slovenia, www.stat.si). N/A = data not available.

\begin{tabular}{lcccc}
\hline Year & $\begin{array}{c}\text { No. of } \\
\text { newborns }\end{array}$ & $\begin{array}{c}\text { No. of } \\
\text { positive } \\
\text { results }\end{array}$ & $\begin{array}{c}\text { No. of } \\
\text { confirmed } \\
\text { cases }\end{array}$ & Incidence \\
\hline 1991 & 21583 & N/A & 9 & $1: 2398$ \\
1992 & 19982 & N/A & 7 & $1: 2855$ \\
1993 & 19793 & N/A & 3 & $1: 6598$ \\
1994 & 19463 & N/A & 8 & $1: 2433$ \\
1995 & 18980 & N/A & 4 & $1: 4745$ \\
1996 & 18788 & N/A & 6 & $1: 3131$ \\
1997 & 18165 & N/A & 4 & $1: 4541$ \\
1998 & 17856 & N/A & 9 & $1: 1984$ \\
1999 & 17533 & N/A & 11 & $1: 1594$ \\
2000 & 18180 & 127 & 14 & $1: 1299$ \\
2001 & 17477 & 176 & 7 & $1: 2497$ \\
2002 & 17501 & 201 & 8 & $1: 2188$ \\
2003 & 17321 & 258 & 14 & $1: 1237$ \\
2004 & 17961 & 238 & 10 & $1: 1796$ \\
2005 & 18157 & 214 & 5 & $1: 3631$ \\
2006 & 18932 & 238 & 8 & $1: 2367$ \\
2007 & 19823 & 187 & 16 & $1: 1239$ \\
2008 & 21817 & 185 & 12 & $1: 1818$ \\
2009 & 21856 & 160 & 4 & $1: 5464$ \\
2010 & 22343 & 195 & 8 & $1: 2793$ \\
2011 & 21947 & 128 & 8 & $1: 2743$ \\
2012 & 21938 & 207 & 9 & $1: 2438$ \\
\hline & & & & \\
\hline
\end{tabular}

\begin{tabular}{|c|c|c|c|c|c|c|c|}
\hline Year & $\begin{array}{c}\text { No. of } \\
\text { newborns }\end{array}$ & $\begin{array}{l}\text { No. of } \\
\text { positive } \\
\text { results }\end{array}$ & $\begin{array}{l}\text { No. of } \\
\text { confirmed } \\
\text { cases }\end{array}$ & $\begin{array}{c}\text { No. of } \\
\text { classic PKU }\end{array}$ & $\begin{array}{l}\text { No. of } \\
\text { moderate } \\
\text { PKU }\end{array}$ & $\begin{array}{l}\text { No. of } \\
\text { mild PKU }\end{array}$ & Incidence \\
\hline 1993 & 19793 & N/A & 5 & 4 & 1 & 0 & $1: 3959$ \\
\hline 1994 & 19463 & N/A & 3 & 2 & 0 & 1 & $1: 6488$ \\
\hline 1995 & 18980 & N/A & 3 & 2 & 0 & 1 & $1: 6327$ \\
\hline 1996 & 18788 & N/A & 2 & 2 & 0 & 0 & $1: 9394$ \\
\hline 1997 & 18165 & N/A & 3 & 1 & 1 & 1 & $1: 6055$ \\
\hline 1998 & 17856 & N/A & 5 & 4 & 1 & 0 & $1: 3571$ \\
\hline 1999 & 17533 & N/A & 2 & 2 & 0 & 0 & $1: 8767$ \\
\hline 2000 & 18180 & 265 & 3 & 1 & 0 & 2 & $1: 6060$ \\
\hline 2001 & 17477 & 167 & 1 & 1 & 0 & 0 & $1: 17477$ \\
\hline 2002 & 17501 & 368 & 0 & 0 & 0 & 0 & I \\
\hline 2003 & 17321 & 476 & 3 & 1 & 0 & 2 & $1: 5774$ \\
\hline 2004 & 17961 & 520 & 6 & 4 & 1 & 1 & $1: 2994$ \\
\hline 2005 & 18157 & 556 & 4 & 3 & 0 & 1 & $1: 4539$ \\
\hline 2006 & 18932 & 154 & 2 & 1 & 0 & 1 & $1: 9466$ \\
\hline 2007 & 19823 & 112 & 1 & 1 & 0 & 0 & $1: 19823$ \\
\hline 2008 & 21817 & 112 & 3 & 2 & 0 & 1 & $1: 7272$ \\
\hline 2009 & 21856 & 196 & 6 & 5 & 0 & 1 & $1: 3643$ \\
\hline 2010 & 22343 & 182 & 4 & 2 & 0 & 2 & $1: 5586$ \\
\hline 2011 & 21947 & 154 & 1 & 0 & 0 & 1 & $1: 21947$ \\
\hline 2012 & 21938 & 157 & 0 & 0 & 0 & 0 & I \\
\hline
\end{tabular}




\section{DISCUSSION}

Worldwide newborn screening started in 1962, in Massachusetts, USA, with the introduction of bacterial inhibition assay for PKU (Guthrie test) (15). Since then, numerous countries have incorporated newborn screening in their public health programmes, and it is, nowadays, an established medical practice in developed countries (3-5). Screening has also expanded to include more diseases, beginning with $\mathrm{CH}$ and galactosemia, while many others were added later on $(3,16)$. More than 10 diseases are screened for in many European countries (17), while in the USA, more than 20 diseases are included in the newborn screening panels $(18,19)$.

With the technological advances came the introduction of tandem mass spectrometry (MS/MS), which allowed accurate measurements of acylcarnitines, amino acids and other metabolites important in diagnosing metabolic disorders (20-22). MS/MS is being increasingly used for newborn screening, as it provides important advantages over other techniques, such as the ability to screen for several diseases in a single run, short time of analysis, selectivity and sensitivity (23).

In the countries of southeastern Europe, including Slovenia, MS/MS has not yet been implemented into newborn screening programmes (24). In Slovenia, a pilot study is under way (25) and will be the first expanded newborn screening in Slovenia, which will make an important contribution in designing the optimal strategy for screening Slovene newborns for inborn errors of metabolism. It will also significantly contribute to the evaluation of the frequency of occurrence of each inborn error of metabolism in our population, as reports from countries that have already incorporated newborn screening showed that prevalences for some diseases are higher than expected (26-29). Slovene newborn screening is an area that should be expanded, and thus brought closer to other countries in the European Union $(17,18)$ and other parts of the developed world $(3,16,30-33)$.

Early detection of PKU and $\mathrm{CH}$ can improve the outcomes of patients (31). One major downside of newborn screening using less sensitive methods is the high number of false positive results. An increase of stress has been shown in parents of infants with false positive screening results (34). With the use of MS/MS, there is a significantly lower number of false positive results (35).

Incidence of classic PKU in Slovenia is 1:10153, while the total incidence of all forms of PKU (classic, moderate and mild PKU) is 1:6769. Incidence of classic PKU in Slovenia between 2001 and 2010, was previously reported to be around 1:10000 (36), which is consistent with here reported data. Incidence of PKU in Europe in 2004, is between 1:3000 and 1:30000 (14). Incidence of $\mathrm{CH}$ in Slovenia, which is $1: 2323$, is on the lower end in Europe, where the incidence is from 1:1300 to 1:13000 (14). Our incidence $(1: 2323)$ is higher than the incidence reported in 2007 in Slovenia, which was 1:3100 (37).

Guidelines in several European countries recommend starting the treatment for PKU as early as possible for the best outcomes (38). Treatment for PKU is with a Phe restricted diet (39). According to the literature, treatment with levothyroxine for $\mathrm{CH}$ should start in newborns within 2 to 3 weeks of age (40). In Slovenia, treatment for both $\mathrm{PKU}$ and $\mathrm{CH}$ starts immediately after the confirmation of the disease, which is within two weeks after birth. This is in line with the previously stated limits of treatment, and shows that newborn screening has been successfully established for the best outcomes of the affected children.

\section{CONCLUSIONS}

The newborn screening programme in Slovenia has been successfully implemented in its public health programme, and has been beneficial for a significant number of affected newborns since the start of the programme. Based on positive experiences in screening for PKU and $\mathrm{CH}$, and on the results from the expansion of screened conditions in developed countries, expansion of screened conditions should be the next step towards a better health programme in Slovenia.

\section{CONFLICTS OF INTEREST}

The authors declare that no conflicts of interest exist.

\section{FUNDING}

This work was partly supported by the Slovenian Research Agency grants J3-6800, J3-6798 and P3-0343.

\section{ETHICAL APPROVAL}

Not required.

\section{REFERENCES}

1. Van Karnebeek CDM, Stockler S. Treatable inborn errors of metabolism causing intellectual disability: a systematic literature review. Mol Genet Metab 2012; 105: 368-81.

2. Howell R, Terry S, Tait VF, Olney R, Hilton CF, Grosse S. et al. CDC grand rounds: newborn screening and improved outcomes. MMWR Morb Mortal Wkly Rep 2012; 61: 390-3.

3. Therrell BL, Adams J. Newborn screening in North America. J Inherit Metab Dis 2007; 30: 447-65. 
4. Burgard P, Cornel M, Filippo FD. Report on the practices of newborn screening for rare disorders implemented in member states of the European Union, candidate, potential candidate and EFTA countries. 2012.

5. Padilla CD, Therrell BL. Newborn screening in the Asia Pacific region. J Inherit Metab Dis 2007; 30: 490-506.

6. Sarnavka V. Rezultati metaboličkog probira u Hrvatskoj. Hrvat Časopis Javno Zdr 2005; 1.

7. Battelino T, Kržišnik C, Pavlin K. Early detection and follow up of children with phenylketonuria in Slovenia. Zdrav Vestn 1994; 63(Suppl 1): s25-8.

8. Kržišnik C, Battelino T, Bratanič N, Hojker S, Pavlin K, Žerjav-Tanšek $M$. et al. Results of screening for congenital hypothyroidism during the ten-year period (1981-1991) in Slovenia. Zdrav Vestn 1994; 63(Suppl 1): s29-31

9. $\quad$ Blau N, van Spronsen FJ, Levy HL. Phenylketonuria. Lancet 2010; 376: 1417-27.

10. Rastogi M V, LaFranchi SH. Congenital hypothyroidism. Orphanet J Rare Dis 2010; 5: 17

11. Lord J, Thomason MJ, Littlejohns P, Chalmers RA, Bain MD, Addison GM. et al. Secondary analysis of economic data: a review of costbenefit studies of neonatal screening for phenylketonuria. J Epidemiol Community Health 1999; 53: 179-86.

12. Geelhoed EA, Lewis B, Hounsome D, O'Leary P. Economic evaluation of neonatal screening for phenylketonuria and congenital hypothyroidism. J Paediatr Child Health 2005; 41: 575-9.

13. Guldberg P, Rey F, Zschocke J, Romano V, François B, Michiels L. et al. A European multicenter study of phenylalanine hydroxylase deficiency: classification of 105 mutations and a general system for genotype-based prediction of metabolic phenotype. Am J Hum Genet 1998; 63: 71-9.

14. Loeber JG. Neonatal screening in Europe: the situation in 2004. J Inherit Metab Dis 2007; 30: 430-8.

15. MacCready RA, Hussey MG. Newborn phenylketonuria detection program in Massachusetts. Am J Public Health Nations Health 1964; 54: 2075-81.

16. Harms E, Olgemöller B. Neonatal screening for metabolic and endocrine disorders. Dtsch Arztebl Int 2011; 108: 11-21.

17. Loeber JG, Burgard P, Cornel MC, Rigter T, Weinreich SS, Rupp K. et al. Newborn screening programmes in Europe; arguments and efforts regarding harmonization. Part 1. From blood spot to screening result. J Inherit Metab Dis 2012; 35: 603-11.

18. Rinaldo $\mathrm{P}$, Zafari S, Tortorelli S, Matern. Making the case for objective performance metrics in newborn screening by tandem mass spectrometry. Ment Retard Dev Disabil Res Rev 2006; 12: 25561.

19. De Jesús VR, Mei JV, Bell CJ, Hannon WH. Improving and assuring newborn screening laboratory quality worldwide: 30-year experience at the Centers for Disease Control and Prevention. Semin Perinatol 2010; 34: 125-33.

20. Levy HL. Newborn screening by tandem mass spectrometry: a new era. Clin Chem 1998; 44: 2401-2.

21. Sweetman L. Newborn screening by tandem mass spectrometry: gaining experience. Clin Chem 2001; 47: 1937-8.

22. Sweetman L. Newborn screening by tandem mass spectrometry (MSMS). Clin Chem 1996; 42: 345-6.

23. Chace $\mathrm{DH}$. Mass spectrometry in newborn and metabolic screening: historical perspective and future directions. J Mass Spectrom 2009; 44: $163-70$.
24. Groselj U, Tansek MZ, Smon A, Angelkova N, Anton D, Baric I. et al. Newborn screening in southeastern Europe. Mol Genet Metab 2014; 113: 42-5.

25. Smon A, Murko S, Repic Lampret B, Battelino T. Pilot research on expanding Slovenian newborn screening programme for inherited metabolic disorders detectable by tandem mass spectrometry. Chem Listy 2014; 108: s182-6.

26. Derks TG, Boer TS, van Assen A, Bos T, Ruiter J, Waterham MR. et al. Neonatal screening for medium-chain acyl-CoA dehydrogenase (MCAD) deficiency in The Netherlands: the importance of enzyme analysis to ascertain true MCAD deficiency. J Inherit Metab Dis 2008; 31: 88-96.

27. Lim JS, Tan ES, John CM, Poh S, Yeo SJ, Ang JSM. et al. Inborn Error of Metabolism (IEM) screening in Singapore by electrospray ionizationtandem mass spectrometry (ESI/MS/MS): an 8 year journey from pilot to current program. Mol Genet Metab 2014; 113: 53-61.

28. Wilcken B, Wiley V, Hammond J, Carpenter K. Screening newborns for inborn errors of metabolism by tandem mass spectrometry. $\mathrm{N}$ Engl J Med 2003; 348: 2304-12

29. Schulze A, Lindner M, Kohlmüller D, Olgemöller K, Mayatepek E, Hoffmann GC. Expanded newborn screening for inborn errors of metabolism by electrospray ionization-tandem mass spectrometry: results, outcome, and implications. Pediatrics 2003; 116: 1399-406.

30. Tarini BA, Christakis DA, Welch HG. State newborn screening in the tandem mass spectrometry era: more tests, more false-positive results. Pediatrics 2006; 118: 448-56.

31. Wilcken B, Haas M, Joy P, Wiley V, Bowling F, Carpenter K. et al. Expanded newborn screening: outcome in screened and unscreened patients at age 6 years. Pediatrics 2009; 124: 241-8.

32. Kasper DC, Ratschmann R, Metz TF, Mechtler TP, Möslinger D, Konstantopoulou V. et al. The national Austrian newborn screening program - eight years experience with mass spectrometry: past, present, and future goals. Wien Klin Wochenschr 2010; 122: 607-13.

33. Pollitt RJ. Introducing new screens: why are we all doing different things? J Inherit Metab Dis 2007; 30: 423-9.

34. Gurian EA, Kinnamon DD, Henry JJ, Waisbren SE. Expanded newborn screening for biochemical disorders: the effect of a false-positive result. Pediatrics 2006; 117: 1915-21.

35. Schulze A, Lindner M, Kohlmüller D, Olgemöller K, Mayatepek E, Hoffmann GF. Expanded newborn screening for inborn errors of metabolism by electrospray ionization - tandem mass spectrometry: results, outcome, and implications. Pediatrics 2003; 111: 1399-406.

36. Grošelj U, Tanšek MŽ, Podkrajšek KT, Battelino T. Genetske in klinične značilnosti bolnikov s fenilketonurijo v Sloveniji. Zdrav Vestn 2013; 82: 767-77.

37. Avbelj M, Tahirovic H, Debeljak M, Kusekova M, Toromanovic A, Krzisnik C. et al. High prevalence of thyroid peroxidase gene mutations in patients with thyroid dyshormonogenesis. Eur J Endocrinol 2007; 156: 511-9.

38. Blau N, Bélanger-Quintana A, Demirkol M, Feillet F, Giovannini M, MacDonald A. et al. Management of phenylketonuria in Europe: survey results from 19 countries. Mol Genet Metab 2010; 99: 109-15.

39. Tanšek MŽ. Fenilketonurija - zgodba o uspešnem zdravljenju presnovne bolezni. Slov Pediatr 2003; 10: 225-35.

40. Balhara B, Misra M, Levitsky LL. Clinical monitoring guidelines for congenital hypothyroidism: laboratory outcome data in the first year of life. J Pediatr 2011; 158: 532-7. 